\title{
OPTIMASI FORMULA DAN KARAKTERISASI PRODUK COOKIES BERBAHAN DASAR PASTA KACANG METE (Anacardium occidentale $L$ )
}

\section{FORMULA OPTIMIZATION AND PRODUCT CHARACTERIZATION OF COOKIES WITH CASHEW NUTS (ANACARDIUM OCIDENTALE L) PASTE AS ITS BASIC INGREDIENT}

\author{
Wawan Agustina ${ }^{1)}$, Nadya Fitri Dzakia ${ }^{2}$, Wisnu Cahyadii'), Diki Nanang \\ Surahman ${ }^{1)}$, Ade Chandra Iwansyah ${ }^{11}$ \\ ${ }^{1)}$ Pusat Penelitian Teknologi Tepat Guna - Lembaga Ilmu Pengetahuan Indonesia \\ Jalan K.S. Tubun No. 5 Subang, 41213 \\ 2)Program Studi Teknologi Pangan, Fakultas Teknik, Universitas Pasundan \\ Jalan Dr. Setiabudhi No.93, Bandung, 40153, Indonesia \\ E-mail: wanwa03@gmail.com
}

Diterima : 03-04-2020
Direvisi :03-06-2020

Disetujui : 19-07-2020

\begin{abstract}
ABSTRAK
Kacang mete merupakan salah satu komoditas potensial dengan kandungan gizi yang baik dan dapat diolah menjadi aneka produk turunannya. Kacang mete dapat diolah menjadi pasta dan selanjutnya dikembangkan menjadi produk cookies. Tujuan penelitian ini adalah untuk memperoleh formula yang optimal pada pembuatan cookies berbahan dasar pasta kacang mete dan tepung terigu. Penelitian yang dilakukan meliputi dua tahap yaitu penelitian pendahuluan dan penelitian utama. Penelitian pendahuluan meliputi karakterisasi kacang mete sebelum dan setelah pemanggangan, pembuatan pasta kacang mete, dan penentuan batas atas dan batas bawah untuk penelitian utama melalui uji hedonik. Penelitian utama meliputi optimalisasi formula cookies berbahan dasar pasta kacang mete dan tepung terigu menggunakan program Design Expert 11.0 Metode D-optimal. Berdasarkan analisis dengan program tersebut dihasilkan formula optimal yaitu dengan penggunaan pasta kacang mete sebanyak $12,52 \%$ dan tepung terigu sebanyak $23,48 \%$ dengan nilai desirability sebesar 0,500 . Berdasarkan hasil analisis fisikokimia, mikrobiologi dan organoleptik dapat disimpulkan bahwa formula optimal pada cookies kacang mete telah memenuhi standar mutu berdasarkan SNI 01-2973-2011 mengenai biskuit.
\end{abstract}

Kata kunci: cookies, design expert, kacang mete, pasta, tepung terigu

\begin{abstract}
Cashew nuts are one of the potential commodities with good nutritional content and can be processed into various derivative products. Cashew nuts can be processed into paste and then developed into cookie products. The purpose of this research was to obtain an optimal formula for making cookies made from cashew nut paste and wheat flour. The research was conducted in two stages, namely preliminary and primary research. Preliminary research consists of characterizing the cashews before and after roasting, making cashew nut paste, and determining the upper and lower limits for the primary research through hedonic testing. The primary research includes optimizing the formula of cookies made from cashew nut paste and flour by using the Design Expert 11.0 D-optimal Method program. Based on the analysis, the optimum formula was produced. As a result, this research found as much as $12.52 \%$ of cashew paste use and $23.48 \%$ of wheat flour use with a desirability value of 0.500 . Based on the physicochemical, microbiological, and organoleptic analysis, it can be concluded that the optimum formula in cashew nut cookies meets the quality standards based on SNI 01-29732011 regarding biscuits.
\end{abstract}


Keywords: cashew nut, cookies, design expert, paste, wheat flour

\section{PENDAHULUAN}

acang mete merupakan salah satu komoditas potensial dengan komponen nutrisi dan nilai jual yang tinggi. Menurut Rico et al., (2016), biji kacang mete mengandung rata-rata sekitar $3,8 \pm 0,8 \%$ air, $21,3 \pm 0,8 \%$ protein, $48,3 \pm 1,6 \%$ lemak dan $144 \pm 32 \mathrm{mg} / \mathrm{kg}$ sodium dan energi sebesar $2525 \pm 35,8 \mathrm{~kJ} / 100 \mathrm{~g}$.

Konsumsi kacang-kacangan dapat memberikan manfaat kesehatan dan belum terkonfirmasi dampak negatifnya (Katarzyna, et al., 2019). Kandungan profile asam lemak sehat dan konsumsi kacang-kacangan telah dikaitkan dengan pengurangan indeks massa tubuh serta dianjurkan untuk diet guna mempertahankan berat badan (Bes-Rastroll et al., 2009). Hasil-hasil riset mengungkapkan bahwa kacang-kacangan termasuk kacang mete kaya akan asam lemak (MUFA, PUFA, dan LA), sumber mikronutrien (kalsium, magnesium, sodium), dan mengandung senyawa antioksidan (Katarzyna, et al., 2019). Konsumsi kacangkacangan juga dilaporkan berperan pada penurunan risiko penyakit degeneratif seperti sakit jantung koroner dan diabetes type 2 (Kendal et al., 2010).

Kacang mete umumnya diolah dengan cara digoreng dan juga digunakan sebagai topping pada berbagai makanan seperti es krim, cokelat batangan, serta aneka kue. Sebagai upaya diversifikasi pangan untuk meningkatkan manfaatnya, kacang mete dapat diolah menjadi pasta yang selanjutnya dapat dibuat menjadi produk olahan berupa cookies. Menurut Hastuti (2012), cookies merupakan makanan yang praktis, dapat dimakan kapan saja dan cukup popular. Cookies adalah salah satu jenis kue kering yang renyah dengan rasa beraneka ragam, berukuran kecil dan tipis. Bahan baku cookies utamanya adalah tepung terigu yang sekaligus berperan dalam pembentukan cookies. Formulasi bahan baku dan bahan penunjang yang digunakan harus sesuai sehingga dihasilkan karakterisitik cookies yang baik. Cookies termasuk friable food. Sifat tekstural friable food yang penting adalah berpori dan mudah terpecah menjadi remah-remah atau partikel-partikel yang tidak teratur selama pengunyahan (Sutomo, 2012).

Menurut Fatkurahman et al., (2012) tahapan proses pembuatan cookies meliputi pencampuran bahan, pencetakan, dan pemanggangan dengan oven. Formula coo kies dapat berbeda-beda tergantung dari bahan-bahan yang digunakan. Pada penelitian pembuatan cookies dari tepung komposit yang dilakukan Hariadi (2017), formula bahan-bahannya meliputi 50,36\% tepung komposit, 18\% tepung gula, 15,3\% margarin, 6,3\% susu bubuk, $5 \%$ telur, $5 \%$ air, 0,02\% baking powder, 0,01\% garam, dan 0,01\% vanili. Penelitian pembuatan cookies dengan substitusi tepung terigu menggunakan tepung kacang mete diketahui substitusi terbaik adalah dengan 30\% tepung kacang mete (Owiredu, et al., 2014).

Optimasi formula pada pembuatan suatu produk dapat dilakukan dengan menggunakan program Design Expert. Program ini dapat mengoptimasi formula dengan beberapa variabel yang dinyatakan dalam satuan respon, menu mixture yang dikhususkan untuk proses formula (Susilo, 2011). Program Design Expert merupakan perangkat lunak yang menyediakan rancangan percobaan untuk melakukan optimasi rancangan produk dan proses (Saleha, 2016). Penelitian ini bertujuan untuk mendapatkan formula optimal cookies berbahan dasar pasta kacang mete (PKM) dan tepung terigu (TT), serta untuk mengetahui karakteristik yang meliputi kimia, fisik, organoleptik, dan mikrobiologi.

\section{METODOLOGI PENELITIAN}

Bahan yang digunakan meliputi kacang mete diperoleh supermarket yang ada di Subang, tepung terigu (TT), gula pasir, margarin, telur, susu bubuk, baking powder dan vanili. Bahan kimia yang digunakan meliputi larutan N-Heksan (Merck, PA), aquadest, alkohol netral, 
larutan Luff-Schoorl, Pb-asetat, $\left(\mathrm{NH}_{4}\right) 2 \mathrm{HPO}_{4} 10 \%$, amilum, $\mathrm{HCl} 25 \%, \mathrm{KI} 20 \%, \mathrm{H}_{2} \mathrm{SO}_{4} 25 \%$, $\mathrm{Na}_{2} \mathrm{~S}_{2} \mathrm{O}_{3}$, indikator fenolftalein dan $\mathrm{NaOH} 30 \%$. Bahan mikrobiologi meliputi Potato Dextrose Agar (Merck), Plate Count Agar (Merck), Buffer Peptone Water (Merck). Bahan pendukung lainnya ialah baking paper, kertas minyak, dan kertas saring. Adapun alat yang digunakan meliputi mixer, oven, neraca digital, loyang, chopper, wadah stainless, wadah plastik, kompor gas, spatula, kuas, dan sendok. Alat yang digunakan untuk analisis kimia meliputi neraca analitik (Mettler Toledo AL 204), alat analisis protein (DuMaster D-480), texture analyser (TA-XTPlus), Furnace (Ney-Vulcan D-130), inkubator (Binder BD-400), oven (Memmert UM 500), autoklaf (HVE-50), cawan porselin, eksikator, tangkrus, loyang, hot plate, erlenmeyer, labu lemak, kertas saring, labu ukur, termometer, refluks, kondensor, tabung reaksi, spiritus, tabung durham, dan cawan petri.

\section{Uji Pendahuluan}

Kegiatan ini meliputi (1) Karakterisasi kacang mete sebelum dan sesudah pemanggangan yang meliputi kadar air dan abu (gravimetri AOAC, 1995), kadar lemak (soxhlet AOAC, 1995), kadar protein menggunakan alat Dumas dan kadar gula total menggunakan metode Luff-schoorl (SNI 01-2891-1992), (2) Pembuatan PKM dan (3) Penentuan formula untuk jumlah batas atas dan batas bawah secara trial and error dan pengujian organoleptik. Kacang dioven pada suhu $150^{\circ} \mathrm{C}$ selama 10 menit kemudian dihaluskan menggunakan chopper hingga membentuk pasta. Formula uji coba dapat dilihat pada Tabel 1. Berdasarkan formula tersebut ditentukan batas atas dan batas bawah dua bahan dasar utama yang akan dioptimasi. Produk cookies dibuat dengan mencampurkan margarin 28,5\%, gula pasir $14,1 \%$ dan telur $14,1 \%$ menggunakan mixer. Kemudian dilakukan pencampuran kedua dengan menambahkan pasta kacang mete dan tepung terigu (sesuai formulasi pada Tabel 1.), susu bubuk $7 \%$, baking powder $0,2 \%$ dan vanili $0,1 \%$ sehingga terbentuk adonan. Selanjutnya adonan dicetak dengan diameter $3,5 \mathrm{~cm}$ dan ketebala sekitar $1 \mathrm{~cm}$, kemudian dipanggang dalam oven pada suhu $150^{\circ} \mathrm{C}$ selama 60 menit. Cookies yang dihasilkan selanjutnya diuji hedonik (uji organoleptik) meliputi warna, aroma, rasa, dan tekstur (mouthfee).

Tabel 1. Formula awal cookies kacang mete pada uji coba pendahuluan

\begin{tabular}{ccc}
\hline Kode Sampel & Pasta Kacang Mete (PKM) $(\%)$ & Tepung Terigu (TT) $(\%)$ \\
\hline 192 & 10,80 & 25,20 \\
\hline 931 & 7,20 & 28,80 \\
\hline
\end{tabular}

Sumber: Modifikasi dari Hariadi (2017) dan Winata (2015)

\section{Penelitian Utama}

Penelitian utama meliputi tahapan (1) penentuan formula menggunakan program $D X,(2)$ pembuatan cookies berdasarkan, (3) pengujian respon (kimia, fisik, dan organoleptik), (4) analisis data respon, (5) Optimasi formula dengan program $D X$ guna memperoleh perbandingan PKM dan TT yang optimal, (6) Verifikasi formula dengan pembuatan produk berdasarkan solusi formula yang ditawarkan program dan pengujian respon yang meliputi (1) respon kimia: kadar air dan abu (Gravimetri: AOAC, 1995), kadar lemak (Soxhlet: AOAC, 1995), kadar protein (Dumas) dan kadar gula total (Luff Schoorl: SNI 01-2891-1992), (2) respon fisik: tekstur (Hardness) menggunakan alat texture analyser, (3) respon organoleptik dengan metode sensori untuk menguji tingkat kesukaan (hedonik) yang meliputi warna, aroma, rasa dan tesktur (mouthfee) (Soekarto, 1985) dengan panelis tidak terlatih sebanyak 30 orang menggunakan skala penilaian 1 sampai 6, (4) Respon mikrobiologi (sampel hari ke0) angka lempeng total dan kapang-khamir (SNI 2897:2008), dan Coliform (APM: SNI 012332.1-2006), (5) analisis asam lemak (GC-MS), (6) nilai kalori (Faktor Atwater-Bryant) dan 
AKG (BPOM RI, 2016). Seluruh pengujian dilakukan di Laboratorium P2TTG-LIPI, kecuali untuk analisis profil asam lemak yaitu di Politeknik Kesehatan Bandung.

\section{HASIL DAN PEMBAHASAN}

Karakterisasi Kacang Mete

Hasil analisis kimia kacang mete sebelum dan setelah pemanggangan dapat dilihat pada Tabel 2.

Tabel 2. Data hasil analisis kimia kacang mete sebelum dan setelah pemanggangan

\begin{tabular}{lcc}
\hline \multicolumn{1}{c}{ Komposisi Kimia } & Kacang Mete Mentah & Kacang Mete Panggang \\
\hline Kadar Air (\%) & 4,94 & 1,40 \\
\hline Kadar Abu (\%) & 2,58 & 2,82 \\
\hline Kadar Protein (\%) & 24,37 & 22,44 \\
\hline Kadar Lemak (\%) & 50,92 & 52,74 \\
\hline Kadar Gula Total (\%) & 1,23 & 2,28 \\
\hline
\end{tabular}

Berdasarkan hasil pengujian, kadar air dan protein kacang mete setelah pemanggangan mengalami penurunan yaitu masing-masing dari 4,94\% menjadi $1,40 \%$ dan $24,37 \%$ menjadi $22,44 \%$. Hal ini karena proses pemanasan pada suhu $150^{\circ} \mathrm{C}$ menyebabkan banyak air yang menguap dan kandungan protein mengalami reaksi maillard selama proses pemanggangan. Sedangkan kadar lemak, abu dan gula total meningkat disebabkan oleh menurunnya kadar air, sementara jumlah komponen tersebut tidak berubah. Menurut Hanifah (2018), berkurangnya kadar air di dalam suatu bahan yang kering akan meningkatkan kandungan padatan yang terdapat di dalam bahan tersebut. Hasil ini hampir sama dengan hasil penelitian Tamrin dan Sandimantara (2014), yang mengungkapkan kandungan kacang mete terdiri dari $21,68 \%$ karbohidrat, $22,92 \%$ protein, $48,81 \%$ lemak $4,28 \%$ air, dan $2,71 \%$.

\section{Formula Dasar dan Variasi Kombinasi Formula}

Hasil uji organoleptik cookies kacang mete berdasarkan formula uji pendahuluan dapat dilihat pada Tabel 3. Hasil uji menunjukkan formula terpilih adalah formula dengan kode 931 yaitu dengan konsentrasi PKM 10,80\% dan TT 25,20\%. Selanjutnya ditentukan batas atas dan batas bawah dari jumlah PKM dan TT dengan menjadikan formula tersebut sebagai nilai tengah dalam penentuan batas atas serta batas bawah varibel berubah untuk optimasi formula.

Tabel 3. Hasil pengujian organoleptik penentuan formula terpilih pada penelitian pendahuluan

\begin{tabular}{ccccc}
\hline \multirow{2}{*}{ Kode Sampel } & \multicolumn{5}{c}{ Atribut Mutu } \\
\cline { 2 - 5 } & Warna & Aroma & Rasa & Tekstur (mouthfee) \\
\hline 192 & 4,57 & 4,33 & 4,57 & 4,57 \\
\hline 931 & 5,03 & 4,90 & 4,90 & 4,77 \\
\hline
\end{tabular}

Keterangan: Skala penilaian 1-6, (6) sangat suka, (5) suka, (4) agak suka, (3) agak tidak suka, (2) tidak suka, dan (1) sangat tidak suka.

Batas bawah dan batas atas kemudian dijadikan sebagai data yang diinput dalam tahap perancangan formula dengan program $D X 11.0$ untuk mencari rancangan formula dari komponen-komponen yang dicampurkan sehingga didapatkan hasil formula yang optimal. Batas bawah dan batas atas kedua komponen variabel berubah tersebut adalah PKM 7,20\% dan $18,00 \%$ dan untuk $\Pi 1$ 18,00\% dan $28,80 \%$. Berdasarkan uji sebelumnya diketahui 
jumlah total variabel berubah adalah $36 \%$ dari basis formula. Nilai ini didapatkan dari hasil penelitian pendahuluan berupa trial and error dengan modifikasi dari Winata (2015). Nilai ini ditentukan sebagai acuan batas atas dan batas bawah formulasi yang diinginkan. Berdasarkan hasil olahan program Design Expert 11.0 diperoleh delapan rancangan formula sebagaimana dapat dilihat pada Tabel 4. Berdasarkan formula tersebut selanjutnya dibuat sampel produk dan dilakukan analisis terhadap nilai respon. Hasil pengujian respon dapat dilihat pada Tabel 5.

Tabel 4. Desain (actua) optimalisasi formula cookies kacang mete dalam design expert

\begin{tabular}{ccc}
\hline Formula & Pasta Kacang Mete (PKM) (\%) & Tepung Terigu (T) (\%) \\
\hline 1 & 11,33 & 24,67 \\
\hline 2 & 18,00 & 18,00 \\
\hline 3 & 7,20 & 28,80 \\
\hline 4 & 9,96 & 26,04 \\
\hline 5 & 8,57 & 27,43 \\
\hline 6 & 12,60 & 23,40 \\
\hline 7 & 14,42 & 21,58 \\
\hline 8 & 16,31 & 19,69 \\
\hline
\end{tabular}

Tabel 5. Data hasil analisis respon kimia dalam design expert 11.0

\begin{tabular}{ccccccccccccc}
\hline $\mathrm{F}$ & $\begin{array}{c}\mathrm{PKM} \\
(\%)\end{array}$ & $\begin{array}{c}\mathrm{T} \\
(\%)\end{array}$ & $\begin{array}{c}\mathrm{KA} \\
(\%)\end{array}$ & $\begin{array}{c}\mathrm{KAb} \\
(\%)\end{array}$ & $\begin{array}{c}\mathrm{KP} \\
(\%)\end{array}$ & $\begin{array}{c}\mathrm{KL} \\
(\%)\end{array}$ & $\begin{array}{c}\mathrm{GT} \\
(\%)\end{array}$ & $\mathrm{H}$ & $\mathrm{W}$ & $\mathrm{A}$ & $\mathrm{R}$ & $\mathrm{T}$ \\
\hline 1 & 11,33 & 24,67 & 2,90 & 1,65 & 8,65 & 35,84 & 4,08 & 4654,48 & 5,00 & 4,83 & 4,83 & 4,73 \\
\hline 2 & 18,00 & 18,00 & 1,91 & 1,73 & 9,56 & 41,93 & 3,15 & 3588,00 & 3,63 & 4,70 & 4,33 & 4,47 \\
\hline 3 & 7,20 & 28,80 & 3,30 & 1,53 & 8,02 & 33,42 & 4,90 & 4991,90 & 4,20 & 4,27 & 4,50 & 4,57 \\
\hline 4 & 9,96 & 26,04 & 3,00 & 1,64 & 8,54 & 35,05 & 4,32 & 4745,76 & 4,20 & 4,50 & 4,70 & 4,70 \\
\hline 5 & 8,57 & 27,43 & 3,20 & 1,61 & 8,14 & 34,25 & 4,72 & 4907,77 & 4,83 & 4,37 & 4,60 & 4,63 \\
\hline 6 & 12,60 & 23,40 & 2,60 & 1,69 & 8,81 & 37,31 & 3,72 & 4515,36 & 4,97 & 4,53 & 4,90 & 4,80 \\
\hline 7 & 14,42 & 21,58 & 2,52 & 1,70 & 8,97 & 38,69 & 3,50 & 4441,10 & 3,50 & 4,57 & 4,40 & 4,53 \\
\hline 8 & 16,31 & 19,69 & 2,50 & 1,72 & 9,46 & 41,51 & 3,27 & 4362,56 & 3,47 & 4,80 & 4,37 & 4,50 \\
\hline
\end{tabular}

Keterangan: $F$ (Formula), PKM (Pasta Kacang Mete), TT (Tepung Terigu), KA (Kadar Air), KAb (Kadar Abu), KP (Kadar Protein), KL (Kadar Lemak), GT (Gula Total), H (Hardness), W (Warna), A (Aroma), $R$ (Rasa), $T$ (Tekstur). Skala nilai respon 1 - 6, (6) sangat suka, (5) suka, (4) agak suka, (3) agak tidak suka, (2) tidak suka, dan (1) sangat tidak suka.

\section{Hasil Analisis Respon}

Secara keseluruhan, hasil analisis respon kadar air, abu, protein, lemak dan hardness texture menunjukkan nilai signifikan. Berdasarkan persamaan yang dihasilkan dari tiap respon diketahui bahwa kedua komponen A dan B yaitu PKM dan TT berpengaruh nyata terhadap respon-respon tersebut, sehingga nilai responnya dapat digunakan untuk proses optimasi.

\section{Hasil analisis respon kadar air}

Hasil analisis dengan Design Expert 11.0, model dari respon kadar air adalah linear. Analisis ragam (ANOVA) pada keseluruhan formula menunjukkan hasil bahwa model yang direkomendasikan signifikan $(p=0,0001)$. Persamaan model matematika untuk respon kimia kadar air dapat dilihat pada persamaan (1). Koefisien dengan kontribusi terbesar terhadap respon kadar air adalah koefisien B yaitu 3,3. Transformasi hasil analisis respon 
kadar air menunjukkan batas bawah kadar air sebesar 1,91\% pada kombinasi PKM 18\% dan TT 18\%, serta batas atas sebesar 3,30\% pada kombinasi PKM 7,20\% dan TT 28,80\%.

Kadar Air $=2,08 \mathrm{~A}+3,33 \mathrm{~B}$.

\section{Hasil analisis respon kadar abu}

Model respon dari kadar abu berdasarkan hasil analisis Design Expert 11.0 adalah quadratic. Analisis ragam pada keseluruhan formula menunjukkan bahwa model yang direkomendasikan signifikan $(p=0,0002)$. Persamaan model matematika untuk respon kimia kadar abu dapat dilihat pada persamaan (2). Komponen yang paling berkontribusi terhadap respon kadar abu adalah koefisien A yaitu 1,72. Transformasi hasil analisis respon kadar abu menunjukkan batas bawah kadar abu sebesar 1,53\% pada kombinasi PKM 7,20\% dan TT 28,80\%, dan batas atas sebesar 1,73\% pada kombinasi PKM 18\% dan TT $18 \%$.

$$
\text { Kadar Abu }=1,72 \mathrm{~A}+1,55 \mathrm{~B}+0,2013 \mathrm{AB}
$$

\section{Hasil analisis respon kadar protein}

Model dari respon kadar protein adalah linear dan berdasarkan analisis ragam keseluruhan formula menunjukkan hasil bahwa model tersebut signifikan $(p=0,0001)$. Persamaan model matematika untuk respon kimia kadar protein dapat dilihat pada persamaan (3). Komponen yang paling besar berkontribusi terhadap respon kadar protein adalah koefisien A dengan nilai 9,60. Transformasi hasil analisis respon kadar protein menunjukkan batas bawah kadar protein sebesar 8,02\% pada kombinasi PKM 7,20\% dan TT $28,80 \%$, serta batas atas sebesar 9,56\% pada kombinasi PKM $18 \%$ dan $\Pi 18 \%$.

Kadar Protein $=9,60 \mathrm{~A}+8,02 \mathrm{~B}$

\section{Kadar Lemak}

Model respon kimia kadar lemak adalah linear dan berdasarkan pada hasil analisis ragam keseluruhan formula menunjukkan bahwa model tersebut signifikan $(p=0,0001)$. Persamaan model matematika untuk respon kimia kadar lemak dapat dilihat pada persamaan (4). Komponen yang paling besar berkontribusi terhadap respon kadar lemak adalah koefisien A yaitu sebesar 42,07. Transformasi hasil analisis respon kadar lemak dari keseluruhan formula menunjukkan batas bawah kadar lemak sebesar 33,42\% dengan kombinasi PKM 7,20\% dan TT 28,80\%, serta batas atas sebesar $41,93 \%$ pada kombinasi PKM $18 \%$ dan TT $18 \%$.

$$
\text { Kadar Lemak }=42,07 \mathrm{~A}+32,94 \mathrm{~B} \text {. }
$$

\section{Hasil Analisis Respon Kadar Gula Total}

Model dari respon kadar gula total adalah quadratic dan berdasarkan hasil analisis ragam Keseluruhan formula menunjukkan hasil bahwa model yang tersebut signifikan $(p=0,0001)$. Persamaan model matematika untuk respon kimia kadar gula total merupakan koefisien dari setiap faktor yang terdapat dalam persamaan (5). Komponen yang paling berkontribusi terhadap respon kadar gula total adalah koefisien B yaitu sebesar 4,97. Transformasi hasil analisis respon kadar gula total keseluruhan formula menunjukkan batas bawah kadar gula total sebesar 3,15\% dengan kombinasi PKM 18\% dan $\Pi 18 \%$, serta batas atas sebesar 4,90\% dengan kombinasi PKM 7,20\% dan $T$ T 28,80\%.

$$
\text { Gula Total }=3,13 \mathrm{~A}+4,97 \mathrm{~B}-1,01 \mathrm{AB} \text {. }
$$

\section{Hasil Analisis Respon Hardness Texture (HT)}

Model dari respon analisis tekstur (hardness) adalah quadratic dan analisis ragam keseluruhan formula menunjukkan hasil bahwa model tersebut signifikan $(p=0,0013)$. Persamaan model matematika untuk respon kimia analisis tekstur ( $H T)$ dapat dilihat pada persamaan (6). Komponen yang paling berkontribusi terhadap respon analisis tekstur 
(hardness) adalah koefisien B dengan nilai 4980,72. Transformasi hasil analisis respon analisis tekstur (hardness) keseluruhan formula menunjukkan batas bawah analisis tekstur (hardness) sebesar 3588 gf dengan kombinasi PKM 18\% dan TT 18\%, serta batas atas sebesar 4991,90 gf dengan kombinasi PKM 7,20\% dan $\Pi \mathrm{T}$ 28,80\%.

$$
H T=3599,85 A+4980,72 B+928,63 A B+2043,72 A B(A-B)+3131,75 A B(A-B)^{2} \ldots
$$

\section{Hasil Analisis Respon Organoleptik}

Model dari respon untuk atribut warna dan aroma adalah linear dan hasil analisis ragam menunjukkan bahwa model pada kedua atribut tidak signifikan. Nilai $\mathrm{p}$ masingmasing sebesar 0,1055 dan 0,0739). Berdasarkan persamaan, kedua komponen (A dan B) tidak berpengaruh nyata terhadap respon atribut warna dan aroma sehingga nilai respon tersebut tidak dapat digunakan untuk proses optimasi. Persamaan model matematika untuk respon atribut warna dapat dilihat pada persamaan (7) dan untuk atribut aroma pada persamaan (8).

Atribut Warna $=3,62 \mathrm{~A}+4,77 \mathrm{~B}$.

Atribut Aroma $=4,72 \mathrm{~A}+4,39 \mathrm{~B}$

Komponen yang paling berkontribusi terhadap respon atribut warna adalah koefisien $B$ dengan nilai 4,77. Transformasi hasil analisis respon atribut warna keseluruhan formula menunjukkan batas bawah atribut warna sebesar 3,47 dengan kombinasi PKM 16,31\% dan TT 19,69\%, serta batas atas sebesar 5,00 dengan kombinasi PKM 11,33\% dan TT 24,67\%. Komponen yang paling besar berkontribusi terhadap respon atribut aroma adalah koefisien $\mathrm{A}$ dengan nilau 4,72. Transformasi hasil analisis respon atribut aroma keseluruhan formula menunjukkan batas bawah atribut aroma sebesar 4,27 dengan kombinasi PKM 7,2\% dan TT 28,8\%, serta batas atas sebesar 4,83 dengan kombinasi PKM 11,33\% dan TT 24,67\%.

Model dari respon untuk atribut rasa dan tekstur (mouthfeel) adalah quadratic dan hasil analisis ragam menunjukkan bahwa model pada kedua atribut tidak signifikan dengan nilai $p$ masing-masing sebesar 0,0739 dan 0,0534. Sama halnya dengan atribut warna dan aroma, bahwa persamaan model matematika dari atribut rasa (9) dan mouthfeel (10) tidak memberikan pengaruh nyata terhadap nilai respon sehingga nilai respon tersebut tidak dapat digunakan untuk proses optimasi.

Atribut Rasa $=4,23 \mathrm{~A}+4,52 \mathrm{~B}+1,38 \mathrm{AB}$

Atribut Tekstur $=4,42 \mathrm{~A}+4,58 \mathrm{~B}+0,7876 \mathrm{AB}$

Komponen yang berkontribusi lebih besar terhadap respon atribut rasa adalah koefisien B dengan nilai 4,52. Transformasi hasil analisis respon atribut rasa keseluruhan formula menunjukkan batas bawah atribut rasa sebesar 4,33 dengan kombinasi proporsi PKM 18,00\% dan TT 18,00\%, serta batas atas sebesar 4,90 dengan kombinasi PKM 12,60\% dan $\mathrm{TT} 23,40 \%$. Sedangkan Komponen yang paling berkontribusi terhadap respon atribut tekstur adalah koefisien $B$ dengan nilai 4,58. Transformasi hasil analisis respon atribut rasa keseluruhan formula menunjukkan batas bawah atribut tekstur sebesar 4,47 dengan kombinasi PKM $18 \%$ dan $\pi$ 18\%, serta batas atas sebesar 4,8 dengan kombinasi PKM $12,60 \%$ dan TT $23,40 \%$.

\section{Hasil Optimalisasi Formula dengan Design Expert 11.0}

Nilai target optimum yang ingin dicapai dikenal dengan nilai desirability dengan rentang nol sampai dengan satu. Nilai desirability adalah nilai fungsi yang dituju dari proses optimasi yang dapat mengungkapkan kemampuan dari program yang digunakan untuk memenuhi target yang diharapkan berdasarkan kriteria yang telah ditetapkan pada produk akhir (Ramadhani et al. 2017). Jika nilai desirability semakin mendekati 1 berarti 
menunjukkan bahwa kemampuan program semakin sempurna untuk dapat menghasilkan produk yang dikehendaki (Raissi dan Farzani, 2009).

Pada proses optimasi, setiap komponen diberi bobot kepentingan untuk mencapai tujuan yang diinginkan. Pembobotan ini dinamakan importance, yang terdapat pilihan tanda positif $1(+)$ hingga tanda positif $5(+++++)$. Semakin tinggi tingkat kepentingan dari komponen dan respon yang diukur, maka semakin banyak tanda positif yang diberikan (Wahyudi, 2012). Penetapan goal dan importance pada PKM, TT dan respon yang lainnya dikarenakan komponen dan respon tersebut merupakan parameter penting yang menentukan kualitas cookies. Selain itu, komponen dan respon tersebut diukur dengan bobot kepentingan tertentu agar formula yang dihasilkan sesuai dengan karakteristik yang diinginkan. Nilai importance yang besar menunjukkkan adanya keinginan untuk mencapai produk yang ideal. Semakin besar nilai importance yang ditetapkan akan semakin sulit untuk mendapatkan hasil dengan nilai desirability yang tinggi (Maulana, 2016). Komponen dan respon, target, batas dan importance pada tahapan optimasi formula dapat dilihat pada Tabel 6.

Tabel 6. Komponen dan respon yang dioptimalisasi, target, batas dan importance pada tahapan optimalisasi formula pada program design expert 11.0

\begin{tabular}{ccccc} 
Nama Komponen/ respon & Goal & Batas Bawah & Batas Atas & Importance \\
\hline Pasta Kacang Mete & is in range & 7,20 & 18,00 & $5(+++++)$ \\
\hline Tepung Terigu & is in range & 18,00 & 28,80 & $5(+++++)$ \\
\hline Kadar Air & Minimize & 1,91 & 3,30 & $3(+++)$ \\
\hline Kadar Abu & Minimize & 1,53 & 1,73 & $3(+++)$ \\
\hline Kadar Protein & Maximize & 8,02 & 9,56 & $3(+++)$ \\
\hline Kadar Lemak & Maximize & 33,42 & 41,93 & $4(++++)$ \\
\hline Kadar Gula Total & is in range & 3,15 & 4,90 & $3(+++)$ \\
\hline Tekstur (Hardness) & is in range & 3558,00 & 4991,90 & $5(+++++)$ \\
\hline Warna & Maximize & 3,47 & 5,00 & $4(++++)$ \\
\hline Rasa & Maximize & 4,33 & 4,90 & $5(+++++)$ \\
\hline Aroma & Maximize & 4,27 & 4,83 & $3(+++)$ \\
\hline Tekstur & Maximize & 4,47 & 4,80 & $5(+++++)$ \\
\hline
\end{tabular}

Berdasarkan hasil optimasi diperoleh solusi formula dengan nilai PKM sebesar $12,52 \%$ dan $T$ sebesar $23,48 \%$ dengan nilai desirability 0,500 . Nilai desirability yang dihasilkan sangat dipengaruhi oleh kompleksitas komponen, kisaran yang digunakan dalam komponen, jumlah komponen dan respon, serta target yang ingin dicapai dalam memperoleh formula optimal (Maulana, 2016). Solusi formula terpilih merupakan formula yang paling optimal dengan nilai desirability 0,500 yang artinya formula tersebut akan menghasilkan produk yang memiliki karakteristik sesuai dengan target optimalisasi sebesar $50 \%$. Formula tersebut terdiri dari PKM $12,52 \%$ dan $\Pi$ 23,48\% yang merupakan variabel berubah. Formula ini diperdiksikan akan memiliki nilai respon diantaranya kadar air 2,72\%, kadar abu 1,68\%, kadar protein 8,80\%, kadar lemak 37,44\%, kadar gula total 3,81\%, analisis tekstur (hardness) 4525,2 gram force, serta nilai organoleptik warna 4,20, rasa 4,70, aroma 4,55 dan tekstur 4,70. Kegiatan optimasi merupakan kegiatan untuk mencapai nilai desirability maksimum. Namun demikian, tujuan optimasi bukan untuk mencari nilai desirability sebesar 1,0 , melainkan untuk mencari kondisi terbaik yang mempertemukan semua fungsi tujuan (Maulana, 2016). 


\section{Verifikasi Formula Hasil Optimalisasi}

Formula optimal yang dihasilkan selanjutnya digunakan dalam pembuatan cookies. Verifikasi dilakukan guna memastikan bahwa hasil prediksi yang diberikan oleh program $D X$ 11.0 metode $D$-optimal dan sesuai dengan nilai aktual dari formula optimal seperti dapat dilihat pada Tabel 8. Selain memberikan nilai prediksi untuk masing-masing respon, program DX 11.0 metode D-optimal juga memberikan Confident Interval (CI) dan Prediction Interval (PI) untuk setiap nilai prediksi respon pada taraf 95\%. Berdasarkan verifikasi yang dilakukan, diketahui bahwa data hasil verifikasi masih sesuai dengan prediksi yang telah dibuat oleh program design expert 11.0. Hal ini ditunjukan oleh nilai respon telah memenuhi $95 \%$ Confident Interval dan 95\% Prediction Interval yang telah diprediksikan oleh program design expert 11.0.

Tabel 8. Hasil Verifikasi pada Formula Optimal Produk Cookies Kacang Mete

\begin{tabular}{|c|c|c|c|c|c|c|}
\hline \multirow{2}{*}{ Respon } & \multicolumn{2}{|c|}{ Hasil } & \multirow{2}{*}{$\begin{array}{c}95 \% \mathrm{CI} \\
\text { low }\end{array}$} & \multirow{2}{*}{$\begin{array}{c}95 \% \text { CI } \\
\text { high }\end{array}$} & \multirow{2}{*}{$\begin{array}{c}95 \% \text { PI } \\
\text { low }\end{array}$} & \multirow{2}{*}{$\begin{array}{c}95 \% \text { PI } \\
\text { high }\end{array}$} \\
\hline & Prediksi & Laboratorium & & & & \\
\hline Kadar Air (\%) & 2,72 & 2,75 & 2,61 & 2,82 & 2,39 & 3,04 \\
\hline Kadar Abu (\%) & 1,68 & 1,72 & 1,66 & 1,70 & 1,64 & 1,73 \\
\hline Kadar Protein (\%) & 8,80 & 8,83 & 8,73 & 8,88 & 8,58 & 9,03 \\
\hline Kadar Lemak (\%) & 37,44 & 37,89 & 36,99 & 37,89 & 36,11 & 38,78 \\
\hline Kadar Gula Total & 3,81 & 3,88 & 3,72 & 3,91 & 3,61 & 4,01 \\
\hline Hardness (gf) & 4545,18 & 4577,10 & 4406,96 & 4643,35 & 4315,88 & 4734,43 \\
\hline Warna & 4,20 & 5,03 & 3,72 & 4,68 & 2,76 & 5,64 \\
\hline Rasa & 4,72 & 5,13 & 4,51 & 4,93 & 4,28 & 5,16 \\
\hline Aroma & 4,55 & 4,90 & 4,43 & 4,68 & 4,18 & 4,93 \\
\hline Tekstur & 4,70 & 4,87 & 4,59 & 4,81 & 4,47 & 4,93 \\
\hline
\end{tabular}

Keterangan: CI (Confident Interval), PI (Prediction Interval)

\section{Karakteristik Produk Formula Optimal}

Karakteristik atau respon dari formula optimal dapat dilihat pada tabel 8. Nilai hasil prediksi oleh Design Expert dan hasil verifikasi analisis di laboratorium pada cookies berbahan dasar PKM dan TT memiliki kandungan untuk respon kadar air, kadar abu dan kadar protein telah memenuhi syarat mutu sesuai SNI 01-2973-2011 cookies yaitu kadar air maksimal 5\%, kadar abu maksimal 2\% dan kadar protein minimal 4\% dengan rasa, aroma dan warna normal. Hasil penelitian Ojinnaka dan Agubolum (2013), mengungkapkan karakteristik cookies kacang mete pada berbagai perbandingan dengan tepung terigu 10 : 90, 20 : 80, 30 : 70, dan 40 60\% memiliki kandungan protein 7,76-11,84\%, kadar air 3,11$5,13 \%$, kadar lemak 16,41-44,34\%, kadar abu 1,82-5,95\%, serat kasar 0,4-1,24\%, dan karbohidrat 34,30-68,00\%.

\section{Respon Asam Lemak}

Hasil analisis asam lemak dengan GCMS pada sampel cookies kacang mete menghasilkan kromatogram dengan delapan (8) puncak dan datanya sebagaimana diinterpretasikan pada Tabel 9. Berdasarkan tabel 9, teridentifikasi sebanyak 8 jenis asam lemak pada sampel cookies kacang mete dengan retensi waktu yang berbeda serta luas dan persen area yang berbeda pula. Luas area terbesar terdapat pada puncak ke-7 yaitu sebesar $34,79 \%$ yang diprediksi sebagai senyawa oleic acid methyl ester (asam oleat) dan termasuk jenis mono unsaturated fatty acid (MUFA). Tingginya senyawa kandungan asam oleat berasal dari kacang mete sebagai salah satu bahan baku utama. Menurut Soares et al., (2013), kacang mete yang diperoleh dari budidaya konvensional dan organik pada berbagai 
tahapan proses mengandung sekitar 6,93 $\pm 0,55 \%$ asam palmitat, $16,99 \pm 0,61 \%$ asam linoleat, 67,62 \pm 1.00 asam oleat, dan 8,42 $\pm 0,55 \%$ asam stearat. Rico et al., (2016) melaporkan bahwa pada kacang mete dari beberapa wilayah berbeda teridentifikasi sekitar 14 asam lemak dengan kandungan tertinggi yaitu sekitar $60,70 \%$ asam oleat, diikuti oleh $17,77 \%$ asam linoleat, 10,2\% asam palmitat dan 8,93\% asam stearat. Pada semi-sweet biscuit dengan lemak dari berbagai sumber kandungan asam lemaknya berkisar antara $40,72-52,60 \%$ asam palmitat, 39,80-48,06\% asam oleat, dan 6,04-11,94\% asam linoleat dan diikuti sejumlah asam lemak lainnya seperti asam stearate dan miristat (Mamat et al., 2012).

Tabel 9. Hasil Analisis Spektrum Massa Kromatogram Cookies Kacang Mete

\begin{tabular}{ccrl}
\hline Peak & Waktu Retensi (Menit) & \% Area & Nama Senyawa (Prediksi) \\
\hline 1. & 4,41 & 1,05 & Caprylic acid methyl ester $\left(\mathrm{C}_{9} \mathrm{H}_{18} \mathrm{O}_{2}\right)$ \\
\hline 2. & 7,05 & 0,86 & Capric acid methyl ester $\left(\mathrm{C}_{11} \mathrm{H}_{22} \mathrm{O}_{2}\right)$ \\
\hline 3. & 10,81 & 8,85 & Lauric acid methyl ester $\left(\mathrm{C}_{13} \mathrm{H}_{26} \mathrm{O}_{2}\right)$ \\
\hline 4. & 15,62 & 3,04 & Myristic acid, methyl ester $\left(\mathrm{C}_{15} \mathrm{H}_{30} \mathrm{O}_{2}\right)$ \\
\hline 5. & 18,55 & 29,92 & Palmitic acid, methyl ester $\left(\mathrm{C}_{17} \mathrm{H}_{34} \mathrm{O}_{2}\right)$ \\
\hline 6. & 20,45 & 14,45 & Linoleic acid, methyl ester $\left(\mathrm{C}_{19} \mathrm{H}_{34} \mathrm{O}_{2}\right)$ \\
\hline 7. & 20,51 & 34,79 & Oleic acid, methyl ester $\left(\mathrm{C}_{19} \mathrm{H}_{36} \mathrm{O}_{2}\right)$ \\
\hline 8. & 20,76 & 7,03 & Stearic acid methyl ester $\left(\mathrm{C}_{19} \mathrm{H}_{38} \mathrm{O}_{2}\right)$ \\
\hline
\end{tabular}

\section{Angka Lempeng Total (ALT), Coliform, dan Angka kapang khamir (AKK)}

Angka lempeng total secara umum tidak berkaitan dengan bahaya keamanan pangan, namun demikian dapat menjadi indikasi yang berkaitan dengan kualitas, umur simpan dan higienitas pada saat proses produksi (Direktorat standardisasi produk pangan, 2012). Berdasarkan hasil analisis, dapat diketahui angka lempeng total cookies kacang mete sebesar $34 \times 10^{1}$. Menurut persyaratan SNI 01-2973-2011 angka lempeng total produk cookies tidak lebih dari $10^{4} \mathrm{koloni} /$ gram produk, sehingga formula cookies berbahan dasar PKM dan TT telah sesuai dengan standar. Winata (2015), diperoleh Angka Lempeng Total pada produk biskuit sebesar $6 \times 10^{1} \mathrm{koloni} / \mathrm{gram}$.

Bahan pangan yang mengandung coliform berarti bahan tersebut telah terkontaminasi kotoran manusia (Aditia dan Muthiadin, 2015). Berdasarkan hasil analisis, diketahui coliform pada cookies kacang mete nilainya $<3,00$ APM/gram. Menurut SNI 01-2973-2011 mengenai coliform bahwa produk cookies harus <20 APM/gram, sehingga cookies berbahan dasar PKM dan $\Pi$ telah sesuai dengan ketentuan SNI. Angka kapang khamir mengindikasikan kontaminasi produk oleh mikroorganisme berupa jamur. Beberapa jenis kapang dan khamir berperan dalam pembusukan pangan dan menghasilkan racun (mikotoksin). Berdasarkan persyaratan SNI 01-2973-2011, angka kapang khamir produk biskuit (cookies) tidak lebih dari $2 \times 10^{2}$ koloni per gram. Hasil analisis jumlah kapang pada cookies berbahan dasar PKM dan $\pi$ sebesar 7,5 $\times 10^{1}$ sehingga telah sesuai dengan standar SNI. Pada penelitian Winata (2015), diperoleh Kapang dan Khamir pada produk biskuit sebesar $3 \times 10^{1}$ koloni/gram yaitu pada kombinasi tepung kacang mete $40 \%$ dan tepung kulit singkong $10 \%$.

\section{Total Kalori dan Angka Kecukupan Gizi (AKG)}

Total kalori yang disajikan adalah hasil konversi zat gizi. Masing-masing setiap gram lemak setara dengan $9 \mathrm{kkal}$, protein setara dengan $4 \mathrm{kkal}$, dan karbohidrat setara dengan 4 kkal (Muchtadi et al., 2018). Takaran saji cookies berbahan dasar PKM dan TT ditetapkan merujuk pada produk komersial sejenis yaitu sebesar 30 gram (Septieni, 2016). Total kalori dari 30 gram cookies yang dihitung dari kadar lemak, protein dan karbohidrat adalah sebesar 
171,471 kkal. Menurut BPOM (2016) tentang acuan label gizi, bahwa asupan energi per hari untuk umum yaitu 2.150 kkal. Konsumsi 30 gram makanan cookies berbahan dasar PKM dan TT dapat memenuhi 7,98\% kalori.

Segmentasi konsumen dari produk cookies kacang mete ini adalah semua kalangan (umum). Satu takaran saji cookies ditentukan sebesar 30 gram yang dapat memenuhi kecukupan 7,98\% energi, 4,51\% karbohidrat, 4,42\% protein, dan 16,97\% lemak. Beberapa gizi kemungkinan menggantikan zat gizi lainnya yang umumnya mempunyai fungsi yang jelas di dalam tubuh (Shinta, 2010). Kandungan Zat Gizi Cookies Kacang Mete per Takaran Saji dapat dilihat pada Tabel 10.

Tabel 10. Kandungan Zat Gizi Cookies Kacang Mete per Takaran Saji

\begin{tabular}{ccccc}
\hline Zat Gizi & $\begin{array}{c}\text { Kandungan Zat } \\
\text { Gizi/ } 100 \mathrm{~g}\end{array}$ & $\begin{array}{c}\text { Kandungan per } \\
\text { Takaran Saji }(30 \mathrm{~g})\end{array}$ & $\begin{array}{c}\text { AKG 2016 } \\
(\text { Umum })\end{array}$ & \%AKG \\
\hline Energi $(\mathrm{kkal})$ & 571,57 & 171,47 & 2150 & 7,98 \\
\hline Karbohidrat $(\mathrm{g})$ & 48,81 & 14,64 & 325 & 4,51 \\
\hline Protein $(\mathrm{g})$ & 8,83 & 2,65 & 60 & 4,42 \\
\hline Lemak $(\mathrm{g})$ & 37,89 & 11,37 & 67 & 16,97 \\
\hline
\end{tabular}

\section{KESIMPULAN}

Berdasarkan pada hasil optimalisasi formula cookies berbahan dasar PKM dan $\Pi$ dengan menggunakan aplikasi Design expert 11.0 diperoleh formula yang optimal yaitu formula dengan $12,52 \%$ PKM dan $23,48 \% \pi$ dan variable tetap lainnya. Niilai desirability formula optimal adalah 0,50. Berdasarkan hasil analisis kimia, fisik, mikrobiologi dan organoleptik dapat diketahui bahwa karakteristik cookies kacang mete dari formula optimal cookies kacang mete telah memenuhi standar mutu berdasarkan SNI 01-2973-2011 mengenai biskuit.

\section{UCAPAN TERIMA KASIH}

Ungkapan terimakasih penulis sampaikan kepada Kepala P2TTG LIPI beserta seluruh sivitas P2TTG LIPI dan pihak-pihak lain yang terlibat dalam kegiatan Prioritas Nasional tahun 2019.

\section{DAFTAR PUSTAKA}

Aditia, L. dan C. Muthiadin. 2015. Uji Kualitas Mikrobiologis Pada Makanan Jajanan di Kampus II Universitas Islam Negeri (UIN) Alauddin Makassar. Biogenesis, Vol 3(2): 119-123

AOAC. 1995. Official Methode of Analysis of the Association Analitical Chemist. Inc., Washington DC. Badan Standarisasi Nasional. 1992. SNI 01-2891-1992: Cara Uji Makanan dan Minuman. Jakarta.

Badan Standarisasi Nasional. 2011. SNI 01-2973-2011: Syarat Mutu Biskuit. Jakarta.

Bes-Rastrollo, M., Wedick N. M., Martinez-Gonzalez M. A., Li T. Y., Sampson L., dan Hu F. B. 2009. Prospective Study of Nut Consumption, Long-Term Weight Change, and Obesity Risk in Women. Am J Clin Nutr. 89:1913-19.

Direktorat Standardisasi Produk Pangan. 2012. Pedoman Kriteria Cemaran pada Pangan Siap Saji dan Pangan Industri Rumah Tangga. Deputi Bidang Pengawasan Keamanan Pangan dan Bahan Berbahaya. BPOM RI. Jakarta

Fatkurahman, R., W, Atmaka, dan Basito. 2012. Karakteristik Sensoris dan Sifat Fisikokimia Cookies Dengan Subsitusi Bekatul Beras Hitam (Oryza sativa L) dan Tepung Jagung (Zea Mays L). Jurnal teknosains pangan. 1(1): 49-57.

Hanifah, N. 2018. Optimasi Formula Cookies Berbahan Baku Tepung Suweg (Amorphophallus campanulatus B) Modifikasi HMT dengan Design Expert Metode Mixture D-Optimal. Tugas AKhir. Program Studi Teknologi Pangan. Universitas Pasundan. Bandung. http://repository.unpas.ac.id/id/eprint/40489. 
Hariadi, H. 2017. Aplikasi Program Linear dalam Pembuatan Formulasi Cookies dari Tepung Komposit (Jagung, Kacang Kedelai dan Bonggol Pisang Batu). Program Studi Teknologi Pangan. Universitas Pasundan. Bandung.

Hastuti, A. Y. 2012. Aneka Cookies Paling Favorit, Populer, Istimewa. Cetakan Pertama. Dunia Kreasi, Jakarta.

Katarzyna, K., P. Alicja, K. Klaudia, dan M. Karolina. 2019. Characterization of Health-Related Properties of Selected Tree-Nuts - A Review. World scientific news, 135: 116-128

Kendall, C. W. C., A. Esfahani, J. Truan, K. Srichaikul, dan D. J. A. Jenkins. Review Health benefits of nuts in prevention and management of diabetes. Asia Pac J Clin Nutr. 19(1):110-116

Mamat, H., M. A. Hamid, dan S. E. Hill. 2012. Major Fatty Acid Composition of Commercial Semi Sweet Biscuit. Borneo Science, 31: 65-70

Maulana, C. 2016. Optimalisasi Formula Tepung Bumbu Ayam Goreng Crispy Berbahan Baku Tepung Singkong (Manihot esculenta Crantz) Modifikasi Autoclaving-Cooling Cycle. Tugas Akhir. Program Studi Teknologi Pangan. Universitas Pasundan. Bandung.

Muchtadi, D., M. Astawan, N. S. Paupi. 2007. Metabolisme Zat Gizi Pangan. Universitas Terbuka, Tangerang Selatan, pp. 1-58. ISBN 9796899744

Ojinnaka, M.C and Agubolum, F.U. 2013. Nutritional and Sensory Properties of Cashew nut-wheat Based Cookies. American journal of food and nutrition, 3(3): 127-134. doi:10.5251/ajfn.2013.3.3.127.134

Owiredu, I., D. Laryea, dan J. Barimah. 2014. Evaluation of Cashew Nut Flour in the Production of Biscuit. Nutrition \& Food Science, 44(3): 204-211. DOI: 10.1108/NFS-06-2013-0067.

Peraturan Kepala BPOM Republik Indonesia No. 9. 2016. Acuan Label Gizi. Berita Negara Republik Indonesia No.792.Jakarta.

Raissi, S. dan R. E. Farzani. 2009. Statistical Optimization through Multi-Response Surface Methodology. World Academi of Science: Engineering and Technology: 267-271

Ramadhani, R. A., D. H. Saputra, B. Tribowo, dan R. D. Kusumaningtyas. 2017. Review Pemanfaatan Design Expert untuk Optimasi Komposisi Campuran Minyak Nabati sebagai Bahan Baku Sintesis Biodiesel. J. Tek. Kim. Ling, 1(1): 11-16. p-ISSN: 2579-8537, e-ISSN : 2579-9746

Rico, R., M. Bullo, dan J. S. Salvado. 2015. Nutritional Composition of Raw Fresh Cashew (Anacardium occidentale L.) Kernels from Different Origin. Food Science \& Nutrition, 4(2): 329-338. DOI: $10.1002 / \mathrm{fsn} 3.294$

Septieni, D. 2016. Mempelajari Pembuatan Cookies Kaya Serat dengan Bahan Dasar Tepung Asia Ubi Jalar. Skripsi. Program Studi Ilmu dann Teknologi Pangan. Institut Pertanian Bogor.

Shinta, A. 2010. Identifikasi Angka Kecukupan Gizi dan Strategi Peningkatan Gizi Keluarga Di Kota Probolinggo. Jurnal SEPA, 7(1):1-5. ISSN 1829-9946

Soares, D. J., P. H. M. de Vasconcelos, A. L. M. Camelo, E. Longhinotti, P. H. de Sousa, dan R. W. de Figueiredo. 2013. Prevalent Fatty Acids in Cashew Nuts Obtained from Conventional and Organic Cultivation in Different Stages of Processing. Food Sci. Technol, Campinas, 33(2):265270. http://dx.doi.org/10.1590/S0101-20612013005000050

Standar Nasional Indonesia (SNI). 2006. Cara Uji Mikrobiologi - Bagian 1: Penentuan Coliform dan Escherichia coli pada Produk Perikanan. Badan Standarisasi Nasional. Jakarta. (SNI 01-2332.12006).

Sudarmadji, Slamet. 2010. Analisis Bahan Makanan dan Pertanian. Penerbit: Liberty. Yogyakarta.

Susilo, E. 2011. Optimasi Formula Minuman Fungsional Berbasis Kunyit (Curcuma domestica Val), Asam jawa (Tamarindus indica linn) dan Jahe (Zingiber officinale var. amarum) dengan Metode Desain Campuran (mixture design). Departemen Ilmu dan Teknologi Pangan, Fakultas Teknologi Pertanian, Institut Pertanian Bogor.

Sutomo, B. 2012. Sukses Wirausaha Kue Kering. Kriya Pustaka. Jakarta.

Tamrin dan M. S. Sadimantara. 2014. Kadar Karaginan Terhadap Karasteristik Kimia Pasta Mete. Jurnal Agriplus. 24(2): 161-168. ISSN 0854-0128.

Wahyudi. 2012. Optimalisasi Formula Produk Ekstruksi Snack Makaroni dari Tepung Sukun dengan Metode Desain Campuran (Mixture Design). IPB. Bogor.

Winata, V. Y. 2015. Kualitas Biskuit dengan Kombinasi Tepung Kacang Mete (Annacardium occidentale L.) dan Tepung Kulit Singkong (Manihot esculenta). Skripsi. Fakultas Atmajaya Yogyakarta Fakultas Teknobiologi Program Studi Biologi. Yogyakarta. http://e-journal.uajy.ac.id/7895/ 